\title{
Памяти Виталия Григорьевича Безрогова
}

\author{
Ольга Евгеньевна Кошелева \\ Институт всеобщей истории РАН \\ Ol'ga Evgen'evna Kosheleva \\ Institute of World History, Russian Academy of Sciences \\ okosheleva@mail.ru
}

Виталий Григорьевич родился в Одессе 16 сентября 1959 г., там до конца своей жизни проживали его дедушка с бабушкой, у которых он проводил свои школьные каникулы. Виталий гордился тем, что он одессит, хотя семья вскоре после его рождения переехала в Москву. Его дед был топографом, и в силу своей деятельности постоянно переезжал с места на место, упаковывая и распаковывая вещи. У него этому научился Виталий: по быстроте и прочности упаковки вещей ему не было равных.

Впрочем, вещей у него всегда было немного, и свое умение Виталий прилагал в первую очередь к упаковке книг. Так получалось, что, куда бы он ни шел, он всегда нес с собой много книг - или купленных, или библиотечных, или отксерокопированных, или ему подаренных, или свои авторские экземпляры, или еще какие-то. Он открывал свой тяжеленный портфель и с виноватой улыбкой говорил: “Я тут вот вам книжку принес.” И это была всегда - замечательная книга. Дело в том, что Виталий Григорьевич был библиоман. Мы, гуманитарии, в общем-то все - библиоманы, но он - это совсем другой случай! Им владела не просто любовь к книгам, а страсть, книги были главной ценностью в его жизни.

Речь идет, конечно, не только и не столько о приобретении книг: если взглянуть на его научные работы, или комментарии к хрестоматиям, то мы увидим к каждому абзацу невообразимое количество сносок. Он целиком и полностью владел литературой по тому, даже незначительному, вопросу, о котором писал. Его советы в отношении историографии были всегда точны и неожиданны, своими знаниями он делился с удовольствием. Но Виталий Григорьевич не только давал советы, он тут же присылал или приносил нужную тебе литературу. Он ходил на все книжные ярмарки и выискивал самые удивительные издания, не только для себя, но и для коллег. За этой любовью к книге у него стояло, видимо, возникшее еще в детстве, благоговейное отношение к авторам, сумевшим создать хорошую книгу. И когда он сам стал автором многих книг, он всегда смущался - ему казалось, что он недостоин быть в числе этой особенной касты.

Виталий Григорьевич всегда хотел стать именно историком Западной Европы. В 1981 г. он поступил на Исторический факультет Московского Педагогического института им. В. И. Ленина, который закончил с отличием. В аспирантуре он работал под руководством Ады Анатольевны Сванидзе над темой по раннесредневековой Ирландии, изучал саги и большой археологический материал. В 1988 г. кандидатская диссертация “Хозяйственная жизнь ирландского общества III - VIII вв.” была успешно защищена и в настоящее время не утратила своего научного значения. Медиевисту трудоустроиться по специальности было нелегко, он работал учителем в школе и методистом в Музее истории и реконструкции Москвы. Вскоре, в 1987 г., ему удалось перейди в Институт Теории и Истории педагогики PAO (сейчас 
Институт Стратегии Развития Образования) в лабораторию Истории зарубежной педагогики до начала Новейшего времени. Проблематика института была близка к его научным интересам, здесь он и проработал всю оставшуюся жизнь.

Едва начав трудиться в должности младшего научного сотрудника, он задумал систематически представить историю образования и педагогики всей Западной Европы, самостоятельно работая в основном с ирландским материалом. Однако ограниченными силами лаборатории этого сделать было невозможно. Чтобы охватить наибольшее количество стран, молодой сотрудник стал привлекать разных специалистов из других учреждений, особенно молодых историков, и выпускать ротапринтные сборники по истории образования в Западной Европе на базе института. Он это делал с увлечением, поняв, что можно самостоятельно создавать новые книги, не только лично осуществляя исследовательскую работу. Они являлись для него неким подготовительным материалом для создания Всемирной истории педагогики.

Виталий продолжал эту деятельность всю жизнь: собирал авторские коллективы и осуществлял новые публикации. Здесь он был неподражаем и внес огромный вклад в исследование истории образования, истории детства, истории учебной литературы. В целом он осуществил подготовку и публикацию около 20 хрестоматий по этим направлениям. Людям нравилось участвовать в проектах Безрогова, было по душе то заинтересованное внимание, с которым он относился к труду каждого, поэтому они не становились утомительным “долгостроем” как это часто бывает с коллективными трудами. Но если кто-то из тех, кого он видел участником проекта, отказывался от этого участия, Виталий Григорьевич упорно и многократно повторял свое предложение, поворачивая его с разных сторон и при этом извиняясь: "простите мне мое занудство....” Обычно эта настойчивость заканчивалась успешно: не помню, чтобы кто-нибудь о своем согласии потом пожалел.

С началом перестройки научная жизнь сильно изменилась: появилась свобода творчества и возможность общаться с зарубежными исследователями, ездить за границу на конференции и работать практически во всех библиотеках мира. И Виталий Григорьевич этими возможностями стал пользоваться максимально. Он относился ко всем своим выступлениям и публикациям очень ответственно - не хотел ударить в грязь лицом перед иностранными коллегами. Круг исследователей, которых Виталий Григорьевич вовлекал в проблемы истории образования и педагогики, чрезвычайно расширился за счет ученых других стран. Увеличился и объем привозимой литературы: он ухитрялся читать на всех языках, пребывая в Германии, постепенно освоил немецкий. Особенно его привлекала возможность широко пользоваться историческими источниками. Не случайно с течением времени Виталий Григорьевич возглавил международный междисциплинарный проект по исследованию истории учебной литературы в сфере начального образования, объединивший более зоо исследователей различных стран.

В 90-е гг. Виталий Григорьевич возглавлял кафедру Педагогической антропологии Университета Российской академии образования. Именно здесь началась работа по истории детства - готовились учебные пособия для чтения курса по истории детства. Перейдя со временем на Кафедру Истории и теории культуры РГГУ, где читался курс по всемирной истории культуры, он основал в этом университете Центр по изучению истории и культуры детства, при котором работал семинар “Культура детства: нормы, ценности, практики.” Незабываемыми остались проводимые им международные конференции - “Аз да буки, книга в руки. История 
учебников начальной школы,” “История детства как предмет исследования: памяти Филиппа Арьеса" и другие.

Увлечение Виталия Григорьевича ранним Средневековьем выразилось и в защищенной в 2004 г. докторской диссертации “Становление образовательных традиций христианской школы в I-V вв.," где он блестяще показал процесс возникновения института школы в европейской традиции, и соперничающий с ней институт ученичества, который до этой работы оставался вне всякого внимания исследователей. В 2006 г. Виталий Григорьевич был избран членомкорреспондентом Российской академии образования. Список его трудов превышает 700 публикаций. Наиболее значимые из них “Учитель и его ученики в текстах Нового Завета," "Возникновение педагогической парадигмы христианства: первая христианская школа в Александрии," “Сравнительная педагогика: неинституализированные формы обучения в образовательных традициях стран Африки, Азии, Европы,” “Традиции ученичества и институт школы в древних цивилизациях.” В 2017 году он был избран сопредседателем Международного общества по изучению учебников и образовательной среды.

При этом сам Виталий Григорьевич никогда не считал себя “выдающимся ученым,” он был предельно скромен, сам себя совсем не ценил, считал себя ужасным занудой и педантом. Но, на самом деле, эти черты проявлялись у него потому, что он был перфекционист - хотел все сделать как можно лучше, тщательнее, полнее. К себе был гораздо требовательнее, чем к другим, и успехам каждого из своих близких искренне радовался больше, чем своим. Под руководством Виталия Григорьевича защищались аспиранты, он был чутким, терпеливым, эрудированным и ответственным научным руководителем.

В целом научная деятельность Виталия Григорьевича была весьма разносторонней и происходила в разных научных учреждениях, разных странах. Например, он тесно сотрудничал с библиотеками, особенно с Научной педагогической библиотекой им. К. Д. Ушинского, создавая на их основе каталоги учебной литературы. Мало кто сейчас знает весь спектр его многогранной деятельности, поскольку Виталий Григорьевич очень скупо говорил о себе. Поэтому так трудно, невозможно написать здесь в полной мере все о нем и о его работе.

Стиль его поведения был истинно джентельменским - он никогда не жаловался, никого не обсуждал и не осуждал, никогда не хвастался и не завидовал, всегда был доброжелателен, честен, галантен, всегда приходил на помощь, был очень настойчив в решении рабочих проблем, но о своей работе предпочитал умалчивать. Уезжая в командировку, не спешил всем сообщать зачем и куда. Тяжело страдая от аллергии, старался это скрывать. И только когда, в очередной раз открыв свой огромный портфель, он, смущаясь, дарил свою новую книгу, можно было понять, какая огромная работа была им над ней проделана.

В последние три года в научной жизни Виталия Григорьевича начался новый, возможно, самый плодотворный, этап - он увлекся архивными разысканиями, работая над историей перевода трудов Яна Амоса Коменского. Им было сделано немало архивных открытий на этом пути, он успел написать прекрасную статью при грантовой поддержке ГИИМ. За новыми открытиями, которые он все же успел сделать, он и поехал в библиотеку университета Лейдена. И больше не вернется никогда... 